Agr. Biol. Chem., 38 (7), $1371 \sim 1376,1974$

\title{
Lipid Molecular Species of Lipomyces starkeyi ${ }^{\dagger}$
}

\author{
Tetsuya Suzuki and Kiyozo Hasegawa \\ Research Institute for Food Science, Kyoto University, Uji, Kyoto 611, Japan
}

Received February 18, 1974

\begin{abstract}
The molecular species of glycerides and phospholipids of the yeast Lipomyces starkeyi IFO 0678 harvested at $60 \mathrm{hr}$, corresponding to the late exponential phase, were analyzed by gas chromatography-mass spectrometry. The major triglyceride was $\mathrm{C}_{16: 0}-\mathrm{C}_{18: 1}-\mathrm{C}_{18: 1}$. The major molecular species of phospholipid were $1-C_{16: 0}-2-C_{18: 1}$ and $1-C_{18: 1}-2-C_{18: 2}$. Although phosphatidylcholine and phosphatidylethanolamine were composed of several kinds

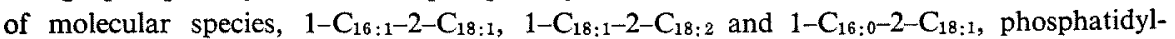
serine was composed of almost exclusively $1-\mathrm{C}_{16: 0}-2-\mathrm{C}_{18: 1}$. The lipid and the fatty acid compositions of the yeast harvested at the different growth phases were also investigated.
\end{abstract}

Fat producing yeasts as Lipomyces starkeyi, $R$. gracilis and $C$. terricolus are expected to be useful fat resources for microorganisms in future fermentation technology. L. starkeyi has been studied for fat production. ${ }^{1 \sim 10)}$ However, the molecular species of the lipid is entirely unknown at the moment. Detailed data on the lipid, including the molecular species, are of interest, not only from the standpoint of technology but also lipid biochemistry. The methods of analysing molecular species of triglycerides and phospholipids are reviewed by Kuksis. ${ }^{11)}$ The conventional methods, however, are elaborate and time consuming, and few such studies on yeast lipid molecular species have been reported. Recently, convenient methods were developed in our laboratory ${ }^{12,13)}$ for molecular species determination of phospholipids and for the analysis of fatty acid distribution in triglycerides by gas chromatography-mass spectrometry (GC-MS).

This paper deals with the analysis of molecular species of the major lipids of $L$. starkeyi. The lipids analyzed included tryglyceride, diglyceride, phosphatidylserine (PS), phosphatidylethanolamine (PE), phosphatidylcholine (PC) and free fatty acid. Changes in the lipid and fatty acid compositions during cultivation were also reported.

+ This report was presented at the 286th Meeting of the Kansai Branch of Agricultural Chemical Society of Japan, Kyoto.

\section{MATERIALS AND METHODS}

Microorganism and culture condition. The microorganism used in this study was Lipomyces starkeyi IFO 0678. The composition of the medium was the same as reported previously, ${ }^{141}$ except $0.3 \%$ of yeast extract was used. After preincubating twice in the medium mentioned above, the cells were cultivated at $28^{\circ} \mathrm{C}$ on a shaker. The growth was followed by measuring the optical density at $660 \mathrm{~nm}$, and the cell number was counted by a haematometer. Consumption of glucose was assayed by the phenol-sulfric acid method. ${ }^{15}$ Aliquots of yeast cells were harvested at $60 \mathrm{hr}, 80 \mathrm{hr}$ and $180 \mathrm{hr}$, corresponding to the late exponential phase, the early stationary phase and the late stationary phase, respectively (Fig. 1). The harvested cells were centrifuged, lyophilized and stored at $-20^{\circ} \mathrm{C}$ until analysis. The lipid analysis was carried out as soon as possible.

Analysis of lipid compositions. The extraction of total lipid was carried out according to Pedersen's method. ${ }^{16)}$ The content of total lipid was measured by the gravimetric method as described previously. 14, The composition of total lipid was analysed by thinlayer chromatography (TLC). ${ }^{14,17)}$ Total lipid was fractionated into neutral lipid, free fatty acid and complex lipid by using silicic acid chromatography, ${ }^{18)}$ and further fractionated into the individual lipids by preparative TLC. ${ }^{13}$ ) Steroid ester, triglyceride, diglyceride and monoglyceride were determined by Antonis' method $^{19)}$ or by gas-liquid chromatography (GLC). ${ }^{201}$ Free fatty acid was analyzed by $\mathrm{GLC}^{13)}$ as methyl ester. $^{21}$ Identification of free sterol was carried out by using UV absorption spectrum ${ }^{221}$ and GC-MS. ${ }^{23}$ ) Content of phospholipid was determined by Bartlett's method. ${ }^{24)}$ The phospholipid composition was analyzed by TLC. ${ }^{14,251}$ Composition of fatty acids of gly- 

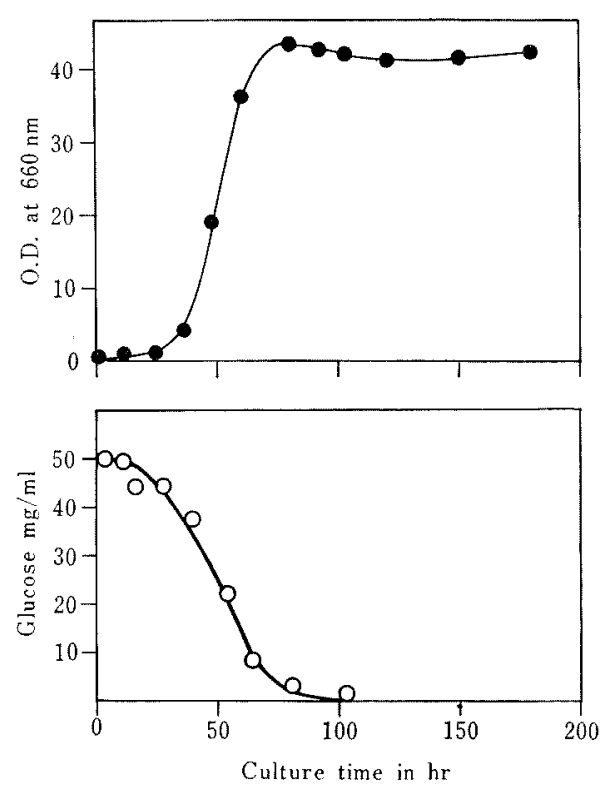

FIg. 1. Cell Growth and Carbon Source Consumption.

ceride and phospholipid was analyzed by $\mathrm{GLC}^{13}$ as methyl ester. ${ }^{26)}$

Positional distribution of fatty acid in glycerides and phospholipids. Analysis of positional distribution of fatty acid in triglyceride was carried out by GC-MS. ${ }^{13}$ The positional distribution of fatty acid in diglyceride was also determined by GC-MS ${ }^{13)}$ after modifying it into trimethylsilyl derivatives. ${ }^{27}$ The analysis of molecular species of phospholipids was carried out by GC-MS as reported previously. ${ }^{12}$

\section{RESULTS AND DISCUSSION}

\section{Cell growth and lipid content}

The growth and the consumption of carbon by L. starkeyi are shown in Fig. 1. The optical densities of the cells harvested at $60 \mathrm{hr}, 80 \mathrm{hr}$ and $180 \mathrm{hr}$ were $37.0,43.2$ and 42.6 , respectively. The approximate cell numbers were respectively $4.0 \times 10^{8}, 4.5 \times 10^{8}$ and $4.3 \times 10^{8}$; the dry cell weights were $6.3,12.0$ and 11.4 $\mathrm{mg} / \mathrm{ml}$; and the total lipid contents were 160 , 380 and $330 \mathrm{mg} / \mathrm{g}$ of dry cell. Although the optical density and the cell numbers from the different growth phases were virtually identical, the dry cell weight for $60 \mathrm{hr}$ was about half of the latter two phases. This observation may be due to the difference of lipid content of the cells.

\section{Lipid composition at different growth phase}

The lipid composition of the three different growth phases are shown in Table I. The most remarkable differences in the three phases of growth were observed with respect to the content of triglyceride and free fatty acid. The data in Table I when considered with those of Fig. 1 indicate that fat was being accumulated while the glucose was being consumed at $60 \mathrm{hr}$. The fat content, especially triglyceride, reached a maximum value at $80 \mathrm{hr}$ when glucose was exhausted, and at $180 \mathrm{hr}$, the cells were in a glucose-deficient state and were consuming their own fat accompanied by a

Table I. Lipid Composition of L. starkeyi Harvested at Different Growth Phases ${ }^{a}$

\begin{tabular}{lcrrrrr}
\hline \multirow{2}{*}{ Lipids } & \multicolumn{2}{c}{$60 \mathrm{hr}$} & \multicolumn{2}{c}{$80 \mathrm{hr}$} & \multicolumn{2}{c}{$180 \mathrm{hr}$} \\
\cline { 2 - 7 } & mg/g cell & (wt. \%) & $\mathrm{mg} / \mathrm{g}$ cell & (wt. \%) & $\mathrm{mg} / \mathrm{g}$ cell & (wt. \%) \\
\hline Steroid ester & trace & $($ trace) & 11.0 & $(2.9)$ & 2.6 & $(0.8)$ \\
Unknown $^{b /}$ & - & $(-)$ & 0.8 & $(0.2)$ & 0.7 & $(0.2)$ \\
Triglyceride & 140.0 & $(87.5)$ & 297.5 & $(78.3)$ & 199.3 & $(60.4)$ \\
Free fatty acid & 0.8 & $(0.5)$ & 0.8 & $(0.2)$ & 71.6 & $(21.7)$ \\
Diglyceride & 1.9 & $(1.2)$ & 15.2 & $(4.0)$ & 6.9 & $(2.1)$ \\
Ergosterol & 5.0 & $(3.1)$ & 15.2 & $(4.0)$ & 8.9 & $(2.7)$ \\
Monoglyceride & trace & $($ trace) & trace & $($ trace) & 9.2 & $(2.8)$ \\
Phospholipid & 12.0 & $(7.5)$ & 38.8 & $(10.2)$ & 31.0 & $(9.4)$ \\
\hline
\end{tabular}

a) Values are expressed as $\mathrm{mg} / \mathrm{g}$ of dry cell weight and weight percentage of total lipids. The average value from two separate experiments is given.

b) The unknown compound is supposed to be alkylether lipid from the results of two dimensional TLC. ${ }^{28}$ 
Table II. Fatty Acid Compositions of TriglyCeride, Free FatTy Acid and Total PhospholipID IN L. starkeyi

\begin{tabular}{|c|c|c|c|}
\hline Fatty acid & $\underset{(\mathrm{mole} \%)}{60 \mathrm{hr}}$ & $\begin{array}{c}80 \mathrm{hr} \\
(\text { mole \%) }\end{array}$ & $\begin{array}{c}180 \mathrm{hr} \\
(\text { mole } \%)\end{array}$ \\
\hline \multicolumn{4}{|l|}{ Triglyceride } \\
\hline $\mathrm{C}_{16: 0}$ & 34.3 & 39.3 & 39.4 \\
\hline $\mathrm{C}_{16: 1}$ & 7.1 & 6.4 & 7.1 \\
\hline$C_{17: 1}$ & trace & 0.6 & 0.6 \\
\hline $\mathrm{C}_{18: 0}$ & 4.3 & 4.9 & 2.3 \\
\hline $\mathrm{C}_{18: 1}$ & 50.6 & 44.5 & 49.4 \\
\hline $\mathrm{C}_{18: 2}$ & 3.7 & 4.3 & 1.1 \\
\hline Unsaturated & 61.4 & 55.2 & 57.6 \\
\hline \multicolumn{4}{|l|}{ Free fatty acid } \\
\hline $\mathrm{C}_{16: 0}$ & 23.9 & 33.4 & 33.3 \\
\hline$C_{16: 1}$ & 8.1 & 5.4 & 3.8 \\
\hline $\mathrm{C}_{18: 0}$ & 1.2 & 8.0 & 7.9 \\
\hline $\mathrm{C}_{18: 1}$ & 66.9 & 49.1 & 51.5 \\
\hline $\mathrm{C}_{18: 2}$ & - & 4.0 & 3.5 \\
\hline Unsaturated & 75.0 & 58.5 & 58.8 \\
\hline \multicolumn{4}{|l|}{ Phospholipid } \\
\hline $\mathrm{C}_{16: 0}$ & 20.8 & 30.6 & 25.9 \\
\hline$C_{16: 1}$ & 10.7 & 10.0 & 6.4 \\
\hline$C_{17: 1}$ & 0.6 & 1.1 & 1.2 \\
\hline $\mathrm{C}_{18: 0}$ & trace & trace & 4.1 \\
\hline$C_{18: 1}$ & 50.6 & 50.3 & 55.5 \\
\hline $\mathrm{C}_{18: 2}$ & 17.3 & 8.0 & 7.0 \\
\hline Unsaturated & 79.2 & 69.4 & 70.1 \\
\hline
\end{tabular}

decrease in triglyceride and an increase in free fatty acid and monoglyceride.

The fatty acid compositions of triglyceride, free fatty acid fraction and phospholipid are shown in Table II. The lipid composition and fatty acid composition of $L$. starkeyi were essentially identical with the data reported earlier,") and also resembled those of $L$. lipoferus. ${ }^{22,29)}$ However, it seemed that the fatty acid composition of each lipid especially in the free fatty acid and phospholipid fractions changed more or less at different growth stages. It was shown that the sum of unsaturated fatty acid of phospholipid was greater than that of triglyceride and free fatty acid fractions at any phases (Table II).

Distributions of fatty acid in diglyceride and triglyceride

At $60 \mathrm{hr}$, the cells are young and the lipid may not be subjected to secondary modifica-
TAble III. Distribution of Fatty ACID IN

Diglyceride and Triglyceride Harvested AT $60 \mathrm{HR}$

\begin{tabular}{|c|c|c|c|c|}
\hline \multirow{2}{*}{$\begin{array}{l}\text { Carbon } \\
\text { number }\end{array}$} & \multicolumn{3}{|c|}{ Fatty acid } & \multirow{2}{*}{ mole $\%$} \\
\hline & $\mathrm{C}-1$ or & $\mathrm{C}-3$ & $\mathrm{C}-2$ & \\
\hline \multicolumn{5}{|c|}{ Diglyceride } \\
\hline 34 & $16: 0$ & & $18: 1$ & $84^{a 1}$ \\
\hline 36 & $18: 1$ & & $18: 1$ & $16^{b 1}$ \\
\hline \multicolumn{5}{|c|}{ Triglyceride } \\
\hline 48 & $16: 0$ & $16: 0$ & $16: 1$ & 1.1 \\
\hline 50 & $16: 0$ & $16: 0$ & $18: 1$ & 30.3 \\
\hline 52 & $16: 0$ & $18: 0$ & $18: 1$ & 6.0 \\
\hline & $16: 0$ & $18: 1$ & $18: 1$ & 47.5 \\
\hline 54 & $\begin{array}{l}18: 1, \\
18: 1\end{array}$ & $\begin{array}{l}18: 1 \\
18: 1\end{array}$ & $\begin{array}{l}18: 1 \\
18: 2\end{array}$ & $15.0^{\circ}$ \\
\hline
\end{tabular}

a) Trace amount of $1(3)-C_{16: 1-2-C_{18: 1}}$ was contained in this fraction.

b) Trace amount of $1(3)-C_{18: 1}-2-C_{18: 2}$ was contained in this fraction.

c) $1,3-C_{18: 1}-2-C_{18: 2}$ was contained only in a small amount.

tion accompanied by decomposition. Thus, distributions of fatty acid in diglyceride and triglyceride of $L$. starkeyi harvested at $60 \mathrm{hr}$ were analyzed. The results are shown in Table III. Since the positions of fatty acid bound to $\mathrm{C}-1$ and $\mathrm{C}-3$ in glyceride cannot be distinguished by GC-MS, convenient nomenclature was used instead of the $s n$-numbering method in Table III. The most abundant type found in diglyceride was $1(3)-C_{16: 0}-2-C_{18: 1}$, and the major type for triglyceride was $1-\mathrm{C}_{16: 0^{-}}$ $2-C_{18: 1}-3-C_{18: 1}$ and/or $1-C_{18: 1}-2-C_{18: 1}-3-C_{18: 0}$ Although data on the distribution of fatty acid in triglycerides in various materials were reported, ${ }^{11,30)}$ few materials were found to contain $\mathrm{C}_{16: 0}-\mathrm{C}_{18: 1}-\mathrm{C}_{18: 1}$ as the major component. But it would appear possible that the composition of the main molecular species of palm oil would resemble that of $L$. starkeyi for the fatty acid composition and that the carbon number distribution of triglyceride of the former was similar to that of the latter. ${ }^{31,32)}$

\section{Molecular species of phospholipid}

After being converted into monoacetyldiglyceride, the phospholipid was subjected to GCMS analysis. The molecular species of total 
Table IV. Molecular Species of Total PhOSPHOLIPID

\begin{tabular}{lccc}
\hline \multirow{2}{*}{$\begin{array}{c}\text { Carbon } \\
\text { number }\end{array}$} & \multicolumn{2}{c}{ Fatty acid } & \\
\cline { 2 - 3 } & $\mathrm{C}-1$ & $\mathrm{C}-2$ & \\
\hline 32 & $16: 0$ & $16: 1$ & 0.4 \\
34 & $16: 0$ & $18: 1$ & 38.0 \\
& $16: 1$ & $18: 1$ & 18.0 \\
36 & $18: 1$ & $18: 1$ & 8.0 \\
& $18: 1$ & $18: 2$ & 35.0 \\
& $18: 2$ & $18: 2$ & trace \\
\hline
\end{tabular}

Table V. Fatty Acid Composition of THE MAJOR PhOSPHOLIPIDS

\begin{tabular}{lccc}
\hline Fatty acid & $\begin{array}{c}\mathrm{PE}^{a)} \\
\left(\text { mole }_{0}\right)\end{array}$ & $\begin{array}{c}\mathrm{PS}^{a)} \\
\left(\mathrm{mole}^{\%}\right)\end{array}$ & $\begin{array}{c}\mathrm{PC}^{a)} \\
\left(\mathrm{mole}^{\circ} \%\right)\end{array}$ \\
\hline $\mathrm{C}_{16: 0}$ & 18.0 & 51.6 & 9.1 \\
$\mathrm{C}_{16: 1}$ & 14.2 & 1.6 & 15.5 \\
$\mathrm{C}_{17: 1}$ & 1.4 & 1.0 & 1.5 \\
$\mathrm{C}_{18: 0}$ & 1.9 & 2.4 & 1.6 \\
$\mathrm{C}_{18: 1}$ & 50.4 & 41.3 & 52.2 \\
$\mathrm{C}_{18: 2}$ & 14.1 & 2.2 & 20.1 \\
Unsaturated & 80.1 & 46.1 & 89.3
\end{tabular}

a) PE, phosphatidylethanolamine; PS, phosphatidylserine; $\mathrm{PC}$, phosphatidylcholine.

Table Vi. Molecular Species of MAJOR Phospholipids

\begin{tabular}{cccc}
\hline \multirow{2}{*}{$\begin{array}{c}\text { Carbon } \\
\text { number }\end{array}$} & \multicolumn{2}{c}{ Fatty acid } & mole \% \\
\cline { 2 - 3 } & $\mathrm{C}-1$ & $\mathrm{C}-2$ & \\
\hline $\begin{array}{c}\text { Phosphatidylethanolamine } \\
34\end{array}$ & & \\
& $16: 0$ & $18: 1$ & 34.7 \\
36 & $16: 1$ & $18: 1$ & 26.1 \\
& $18: 1$ & $18: 1$ & 11.2 \\
& $18: 1$ & $18: 2$ & 28.0 \\
\hline Phosphatidylserine & & & \\
32 & $16: 0$ & $16: 0$ & 0.8 \\
& $16: 0$ & $16: 1$ & 3.1 \\
34 & $16: 0$ & $18: 1$ & 91.9 \\
& $16: 0$ & $18: 2$ & 4.2 \\
\hline Phosphatidylcholine & & & \\
34 & $16: 0$ & $18: 1$ & 16.8 \\
& $16: 1$ & $18: 1$ & 29.6 \\
36 & $18: 1$ & $18: 1$ & 18.4 \\
& $18: 1$ & $18: 2$ & 28.8 \\
& $18: 2$ & $18: 2$ & 6.4 \\
\hline
\end{tabular}

phospholipid are shown in Table IV. The major molecular species of total phospholipid were $1-\mathrm{C}_{16: 0}-2-\mathrm{C}_{18: 1}$ and $1-\mathrm{C}_{18: 1}-2-\mathrm{C}_{18: 2 .}$. The phospholipid mainly consisted of PC (44\%), PE $(30 \%)$ and PS $(25 \%)$. Small amounts of phosphatidylinositol (PI) and phosphatidylglycerol (PG) were also detected. The fatty acid compositions of the major phospholipids are given in Table V. It is obvious that considerable differences are present in the fatty acid composition among three phospholipids, especially in PS. As shown in Table VI, it was found that the individual phospholipid was composed of characteristic molecular species. The major molecular species of $\mathrm{PE}$ were $1-\mathrm{C}_{16: 0}-2-\mathrm{C}_{18: 1}, \quad 1-\mathrm{C}_{18: 1}-2-\mathrm{C}_{18: 1}$ and 1-

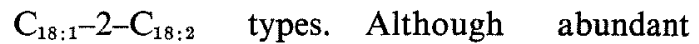
molecular species of $\mathrm{PC}$ were similar to those of $\mathrm{PE}$, the proportion of $1-\mathrm{C}_{16: 0}-2-\mathrm{C}_{18: 1}$ and $1-C_{16: 1}-2-C_{18: 1}$ in $P C$ showed a contradictory relationship to that of PE. The molecular species of PS was rather simple. More than $90 \%$ of PS was composed of a single molecular species, $1-\mathrm{C}_{16: 0}-2-\mathrm{C}_{18: 1}$. It is noteworthy that the most abundant type of diglyceride is 1 (3) $-\mathrm{C}_{16: 0}-2-\mathrm{C}_{18: 1}$ (Table III). That the same molecular species occupy the main part of diglyceride and PS would suggest that diglyceride and PS are located in positions close to a common precursor, phosphatidic acid. ${ }^{331}$ The findings that PE and PC are composed of several kinds of molecular species would suggest that the exchange of fatty acid of phospholipid by the deacylation-reacylation mechanism $^{34}$ 36) takes place at $\mathrm{PE}$ and $\mathrm{PC}$, and not at PS. If PE is assumed to be synthesized prior to PS in the order as observed in animal tissues, no simple explanation for the molecular species of PS in comparison with those of PE can be offered. The degree of unsaturation of fatty acid in PE and PC as compared with those of PS was nearly doubled, as seen in Tables V and VI. Kates and Paradis ${ }^{37}$ recently reported that in $C$. lipolytica the formation of more unsaturated molecular species of PE and PC was carried out by direct phospholipid desaturation in spite of the deacylation -reacylation mechanism. By direct desatura- 
tion of phospholipid, the degree of unsaturation increases which is not accompanied by a change in the carbon number of the fatty acids. Since the observed change of fatty acid in $\mathrm{C}-1$ position take place not only from $\mathrm{C}_{16: 0}$ to $\mathrm{C}_{16: 1}$ but also from $\mathrm{C}_{16: 0}$ to $\mathrm{C}_{18: 1}$, it is not possible to explain this phenomenon using only Kates' mechanism. The exchange of fatty acid by deacylation-reacylation mechanism would take place at PE and PC.

Some explanation to the above problems may be achieved by incubating the yeast in different culture conditions, and investigating the changes in the molecular species of phospholipids. The changes of the molecular species of phospholipids along with changes of fatty acid distribution in glycerides of the cells incubated in glucose-sufficient and/or glucosedeficient media will be reported in another paper. ${ }^{38)}$

Acknowledgement. The authors express their thanks to Prof. K. Iwai, Research Institute for Food Science, Kyoto University, for his kind advice and encouragement, and to Prof. H. Yamada, Research Institute for Food Science, Kyoto University, for his valuable advice in yeast cultivation.

\section{REFERENCES}

1) R. L. Starkey, J. Bacteriol., 51, 33 (1946).

2) D. R. Cullimore and M. Woodbine, Nature, 190, 1022 (1961).

3) S. Akiyama, T. Fukasa, Y. Uzuka and K. Tanaka, Abstracts of Papers, Annual Meeting of Agricultural Chemical Society of Japan, Tokyo, April, 1971 , p. 20.

4) S. Sodeyama, Y. Uzuka and K. Tanaka, Abstracts of Papers, Annual Meeting of Agricultural Chemical Society of Jäpan, Sendai, April, 1972, p. 206.

5) S. Akiyama, T. Koga, T. Naganuma, Y. Uzuka and K. Tanaka, Abstracts of Papers, Annual Meeting of Agricultural Chemical Society of Japan, Sendai, April 1972, p. 207.

6) H. Korenaga, T. Naganuma, Y. Uzuka and K. Tanaka, Abstracts of Papers, Annual Meeting of Agricultural Chemical Society of Japan, Tokyo, April, 1973, p. 122.

7) T. Kanamori, Y. Uzuka and K. Tanaka, Abstracts of Papers, Annual Meeting of Agricultural Chemical Society of Japan, Tokyo, April, 1973, p. 121 .
8) T. Kanamori, Y. Uzuka and K. Tanaka, Abstracts of Papers, 45th Annual Meeting of the Japanese Biochemical Society, Tokyo, November, 1972 , p. 799.

9) T. Naganuma, Y. Uzuka, K. Tanaka, T. Koga and H. Korenaga, Abstracts of Papers, 46th Annual Meeting of the Japanese Biochemical Society, Nagoya, September, 1973, p. 457.

10) T. Ya. Batrina, M. V. Zalashko and V. V. Gerbeda, Vesti Akad. Navuk Belaruss. S. S. R., Ser. Biyal. Navuk, 1972, 67 [C. A., 77, 135579f (1972)].

11) A. Kuksis, "Progress in the Chemistry of Fats " and Other Lipids," Vol. 12, ed. by R. T. Holman, Pergamon Press, Oxford, 1972, pp. 1 165.

12) K. Hasegawa and T. Suzuki, Lipids, 8, 631 (1973).

13) T. Suzuki and K. Hasegawa, Agr. Biol. Chem., 38, 613 (1974).

14) T. Suzuki, A. Takigawa and K. Hasegawa, ibid., 37, 2653 (1973).

15) M. Dubois, K. A. Gilles, J. K. Hamilton, P. A. Rebers, and F. Smith, Anal. Chem., 28, 350 (1956).

16) T. A. Pedersen, Acta Chem. Scand., 16, 374 (1962).

17) D. C. Mallins and H. K. Mangold, J. Am. Oil Chemist's Soc., 37, 576 (1960).

18) J. C. Dittmer and M. A. Wells, "Methods in Enzymology," Vol. 14, ed. by J. M. Lowenstein, Academic Press, New York, 1969, p. 511.

19) A. Antonis, J. Lipid Res., 1, 485 (1960).

20) A. Kuksis, J. Am. Oil Chemist's Soc., 42, 269 (1965).

21) H. Schlenk and J. L. Gellerman, Anal. Chem., 32, 1412 (1960).

22) F. A. McElroy and H. B. Stewart, Can. J. Biochem., 45, 171 (1970).

23) C. J. W. Brooks, W. Hendersen and G. Steel, Biochim. Biophys. Acta, 296, 431 (1973).

24) G. R. Bartlett, J. Biol. Chem., 234, 466 (1959).

25) V.P. Skipski, R. F. Peterson and M. Barclay, Biochem. J., 90, 374 (1964).

26) W. Stoffel, F. Chu and E. H. Ahrens, Anal. Chem., 31, 307 (1959).

27) M. Barber, T. O. Merren and W. Kelley, Tetrahedron Lett., 18, 1063 (1964).

28) H. H. O. Schmid and H. K. Mangold, Biochim. Biophys. Acta, 125, 182 (1966).

29) M. V. Zalashko, V. D. Andreevskaya, N. V. Obraztsova and V.V. Gerbeda, Vesti Akad. Navuk Belaruss. S.S.R., Ser. Biyal. Navuk, 1972, 69 [C. A., 76, 124056m (1972)].

30) T. Murata and S. Takahashi, Anal. Chem., 45, 1816 (1973).

31) A. C. Clegg, J. Am. Oil Chemist's Soc., 50, 321 (1973).

32) A. Kuksis, cited in reference 11, p. 58.

33) K. Hunter and A. H. Rose, "The Yeast," Vol. 2, ed. by A. H. Rose, Academic Press Inc., New York, 1971, p. 237. 
34) E. E. Hill and W. E. M. Lands, Biochim. Biophys. Acta, 152, 645 (1968).

35) H. Van Den Bosch, A. J. Slotboom and L. L. M. Van Deenen, ibid., 176, 632 (1969).

36) M. Kito, S. Aibara, M. Kato and T. Hata, ibid.,
260, 475 (1972).

37) M. Kates and M. Paradis, Can. J. Biochem., 51, 184 (1973).

38) T. Suzuki and K. Hasegawa, Agr. Biol. Chem., in press. 